\title{
33 OMDLENIA - PIERWSZA KRAKOWSKA ADAPTACJA TEATRALNA ROSYJSKIEJ KLASYKI PO 1989 ROKU
}

\author{
Magdalena Karlikowska-Pąsiek \\ Wydziałowe Kulturoznawcze Studia Doktoranckie \\ Uniwersytet Jagielloński, ul. Gołębia 24, 31-007 Kraków \\ E-mail: magdalena.karlikowska@uj.edu.pl \\ ORCID: https://orcid.org/0000-0003-1716-9745
}

\section{Abstrakt}

Cel badań. Celem badań było sprawdzenie, które wątki trzech dramatów Antoniego Czechowa (Niedźwiedź, Oświadczyny, Jubileusz) polski reżyser pominął lub zmienił $\mathrm{i}$ jaki jest tego efekt dla pierwszej krakowskiej adaptacji teatralnej tychże utworów po 1989 roku jako całości.

Metoda badań. Przedmiotem badań był scenariusz Tadeusza Pawłowicza wystawiony w krakowskim teatrze Bagatela 8 kwietnia 1989. W pracy został przeanalizowany polski scenariusz adaptacji utworów: Niedźziedź, Oświadczyny oraz Jubileusz. Poprzez wyodrębnienie pominiętych w scenariuszu teatralnym bohaterów oraz wątków utworów Antoniego Czechowa, zostanie zbadany przekład dzieła literackiego na dzieło sceniczne. $W$ ten sposób będziemy mogli się dowiedzieć, które epizody utworów zostały pominięte, a które dodane w przekładzie.

Wyniki badań. Analiza wykazała, że Tadeusz Pawłowicz przenosząc dzieło literackie $\mathrm{z}$ jednej formy do drugiej (dzieło literackie - teatr) i z jednej kultury do drugiej (Rosja - Polska) dokonał marginalnych skreśleń, pozostając tym samym wiernym tekstowi Czechowskich utworów oraz nie dopisał dodatkowych, autorskich partii tekstu. Ponadto, reżyser realizując 33 omdlenia powielił pomysł na połączenie trzech wodewili czechowskich w jedną inscenizację Wsiewołoda Meyerholda z 1935 roku.

Wnioski. W badaniu zostały wzięte pod uwagę aspekty przekładu dzieła literackiego na dzieło sceniczne. Badanie modyfikacji treści oryginalnego tekstu oraz przekładu nie ma na celu oglądu spostrzeżeń polskiego widza. Uzyskane wyniki przedstawiają jedynie możliwości odkodowania i zrozumienia najważniejszych wątków utworów, jaką widzowi daje reżyser.

Słowa kluczowe: Czechow, Kraków, teatr, literatura, Polska, Rosja, 33 omdlenia.

\section{3 collapses - the first post-1989 Krakow theatre adaptation of a Russian}

Abstract

Purpose of research. The aim of the research was to check which threads of Anton Chekhov's three dramas (The Bear, The Announcement, and Jubilee) were omitted or

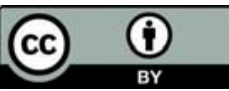


changed by the Polish director, and what effect this had on the first post- 1989 Krakow [or Cracow] theatrical adaptation of these works as a whole.

Methodology. The subject of the research was Tadeusz Pawłowicz's script staged at the Bagatela theatre in Krakow on 8 April, 1989. The research analysed the Polish script used in adapting three works: The Bear, The Announcement and Jubilee. The translation of a literary work into a stage work are examined by distinguishing the characters omitted from the theatrical script as well as the themes of Anton Chekhov's works. In this way we can answer the question of which episodes of the works were omitted and which were added in the translation.

Results. The analysis showed that Tadeusz Pawłowicz, by transferring a literary work from one form to another (literary - theatre) and from one culture to another (Russian - Polish), made marginal deletions, thus remaining faithful to the text of Chekhovian works and did not add his own original parts to the text. Moreover, the director, while making 33 collapses copied the idea of combining three of Chekhov's vaudeville pieces into one production, Vsevoloda Meyerhold from 1935.

Conclusions. The study took into account the aspects of translating a literary work into a stage work. The study of the modification of the content of the original text and the translation is not intended to examine the insights of the Polish viewer. The results obtained merely show the possibility of decoding and understanding the most important themes in the works that the director gives the viewer.

Key words: Chekhov, Krakow, theatre, literature, Poland, Russia, 33 collapses.

\section{WPROWADZENIE}

Przedstawienie 33 omdlenia w reżyserii Tadeusza Pawłowicza było pierwszą adaptacją teatralną rosyjskiej klasyki po 1989 roku w Krakowie ${ }^{1}$. Przez pojęcie „rosyjska klasyka” autorka artykułu rozumie twórczość Fiodora Dostojewskiego, Nikołaja Gogola i Antoniego Czechowa. Wybór niniejszych autorów został podyktowany następującym faktem: po 1989 roku w polskim teatrze utwory Gogola, Dostojewskiego i Czechowa były najczęściej oraz najchętniej adaptowane na potrzeby sceniczne przez rodzimych i zagranicznych reżyserów spośród wszystkich rosyjskich pisarzy. 33 omdlenia to sceniczna adaptacja trzech jednoaktówek Czechowa: Niedźwiedź (ros. Медведь, 1888), Оświadczyny (ros. Предложение, 1888) oraz Jubileusz (ros. Юбилей, 1892). Pomysłodawcą połączenia wspomnianych trzech wodewili Czechowa w jedną inscenizację był Wsiewołod Meyerhold, który w 1935 roku z okazji 75 rocznicy urodzin pisarza zrealizował sceniczną adaptację pt. 33 omdleń. Krakowska premiera nie była pierwszą aranżacją 33 omdleń Pawłowicza. Przed rokiem 1989 Pawłowicz wystawił 33 omdlenia 5 marca 1988 roku w warszawskim Teatrze Dramatycznym. W badanym okresie na krakowskiej scenie teatralnej 33 omdlenia były adaptowane dwukrotnie. Po raz pierwszy po transformacjach ustrojowych zaadaptował utwory Czechowa przywołany już Pawłowicz. Druga premiera odbyła się 4 stycznia 1994 roku w Teatrze STU. Wówczas przedstawienie wyreżyserował Zbigniew Zapasiewicz, który w 1988 roku

133 omdlenia adaptacja teatralna w reżyserii Tadeusza Pawłowicza wystawiona w Teatrze Bagatela im. Tadeusza Boya-Żeleńskiego w Krakowie - premiera 8 kwietnia 1989 roku. 
w inscenizacji Pawłowicza wcielił się w role Łomowa, Smirnowa oraz Chirina. Zapasiewicz zrealizował również jedyną w Polsce inscenizację 33 omdleń w ramach Teatru Telewizji - 9 lipca 1997 roku.

\section{TRANSFORMACJE USTROJOWE A PIERWSZA ADAPTACJA 33 OMDLEN Po 1989 ROKU}

Należy nadmienić, że inscenizacja 33 omdleń Pawłowicza na krakowskiej scenie Bagatela obyła się w przełomowym dla Polski roku. Transformacja teatru po $1989 \mathrm{r}$. polegała m.in. na prywatyzacji niektórych scen, zamykaniu wybranych placówek oraz zmianie sposobu finansowania, działalności organizacyjnej i samym funkcjonowaniu poszczególnych instytucji kultury. Niewątpliwie taka reforma polskiej sceny teatralnej wpłynęła również na oferowany repertuar. Nowa, powstała właśnie rzeczywistość, a przede wszystkim nowe sposoby dotowania instytucji kultury, jeszcze niedopracowane do końca w 1989 roku, sprawiły, że przedstawienie teatralne w tym okresie zaczęło funkcjonować jako produkt, który trzeba sprzedać widzowi, aby zapewnić teatrom płynność finansową. Nowe realia stworzyły intrygujące możliwości, ale także problemy, które wpłynęły na kształt i odbiór powstających inscenizacji. Największym wyzwaniem z jakimi musiały się zmierzyć 33 omdlenia Pawłowicza oraz inne przedstawienia, których premiera przypadła na rok 1989, były wydarzenia o charakterze polityczno - gospodarczym. Jednym z najważniejszych momentów historycznych we wspomnianym okresie były obrady Okragłego Stołu, które trwały od 6 lutego do 4 kwietnia 1989 roku. Wszystko to sprawiło, że sama premiera 33 omdleń Pawłowicza była przez prasę potraktowana marginalnie. Większość krajowych wydań była poświęcona tematyce Okrągłego Stołu i Lechowi Wałęsie. W gazetach nie tylko brakowało informacji o zbliżających się premierach, ale także fachowych recenzji teatralnych. Jedyną wzmianką $\mathrm{w}$ prasie o premierze 33 omdleń była krótka informacja zamieszczona w Kronice Krakowskiej na łamach Dziennika Polskiego - 6 kwietnia 1989, która brzmiała następująco:

„W sobotę 8 bm. o godz. 19:15 w Teatrze Bagatela odbędzie się premiera spektaklu zatytułowanego 33 omdlenia - w oparciu o humoreski teatralne Antoniego Czechowa. Ich adaptacji dokonał reżyser przedstawienia Tadeusz Pawłowicz” („Dziennik Polski”, s.8).

Trzeba pamiętać, że wówczas w Polsce nie istniało takie medium jak Internet. Stąd afisze oraz recenzje teatralne były publikowane tylko $w$ prasie. Jedną $\mathrm{z}$ funkcji fachowej publicystyki teatralnej jest omówienie najważniejszych niuansów spektaklu - w tym nośnych symboli, zaczerpniętych z obcego kręgu kulturowego, co niewątpliwie ma miejsce $\mathrm{w}$ przypadku adaptacji rosyjskiej literatury na polskie warunki. Dlatego warto zastanowić się, które wątki dzieła literackiego zostały przeniesione na dzieło sceniczne, a które pominięte lub dodane. Takie działanie pozwoli ocenić możliwość odkodowania i zrozumienia najważniejszych fragmentów fabuły utworu literackiego. Trzeba także uwzględnić fakt, że brak fachowego omówienia spektaklu w prasie może przyczynić się do niezrozumienia niektórych symboli. Warto pamiętać, że znaczna część współczesnej publiczności teatralnej nie posiada przedrozumienia kultury rosyjskiej. „Przedrozumienie oznacza sytuację, w której adresat przedstawienia idzie do teatru z pewnym wyobrażeniem bohaterów i fabuły. Wyobrażenie to zostało ukształtowane przez konteksty kulturowe. W momencie, gdy obserwator teatralny nie posiada przedrozumienia, bo jest przedstawicielem kultury polskiej i nie zna kultury rosyjskiej, nie zrozumie nie- 
których niuansów przedstawienia. Przeciętnemu widzowi brakuje odpowiedniego zaplecza naukowego oraz chęci do odczytywania utworu inaczej, niż poprzez własne doświadczenia życiowe" (Hübner, 2014, s. 85-86). Brak odpowiedniego zaplecza naukowego i wiedzy zapewne sprawiło, że wielu widzów 33 omdleń nawet nie wiedziało, że pierwszy raz w historii teatru te trzy żarty sceniczne Czechowa w jedno przedstawienie połączył już w 1935 roku Wsiewołod Meyerhold. Dodatkowo warto wspomnieć, że 33 omdlenia przygotował polski reżyser dla polskiej publiczności, co mogło sprawić, że treść dzieła scenicznego mogła być znacznie zmodyfikowana $\mathrm{w}$ stosunku do rosyjskiego pierwowzoru, a charakterystyczne dla tych utworów symbole oraz postacie pominięte w przekładzie. Odbiorca bez przedrozumienia może nawet tego nie zauważyć. Dlatego - bez wątpienia - brak recenzji oraz zainteresowania problematyką teatru ze strony dziennikarzy $w$ tamtym okresie, a także wszechobecna $\mathrm{w}$ publicystyce tematyka związana z przemianami ustrojowymi i niechęć do wszystkiego, co rosyjskie, mogła przyczynić się do niezrozumienia niektórych wątków 33 omdleń Pawłowicza.

\section{Analiza scenariusza 33 omdleń Paweowicza}

Analizę scenariusza należy rozpocząć od wyodrębnienia skrótów, jakich dokonał polski twórca teatralny. Pominięte przez Pawłowicza wątki można ukazać poprzez wyróżnienie bohaterów utworów Czechowa, którzy zostali uwzględnieni w inscenizacji. W adaptacji Pawłowicza występują następujące postacie: Natalia Stiepanowna (Oświadczyny), Łomowa (Oświadczyny), Smirnowa (Niedźwiedź), Łomow (Oświadczyny), Smirnow (Niedźwiedź), Chirin (Jubileusz), Czubukow (Oświadczyny), Łuka (Niedźwiedź) oraz Szypuczin (Jubileusz). Warto nadmienić, że w przedstawieniu występuje tylko trzech aktorów. Rolę Natalii Stiepanownej, Łomowej oraz Smirnowej gra jedna aktorka. Rolę Łomowa, Smirnowa oraz Chirina gra jeden aktor. Łukę i Szypuczina również gra jeden aktor.

Przedstawienie Pawłowicza rozpoczyna scena jednoaktówki Oświadczyny, w której Łomow przychodzi do Czubukowa poprosić o rękę jego córki - Natalii. Następnie autor adaptacji wiernie podąża za tekstem Czechowa, tzn. nie dokonuje żadnego skrótu w tekście rosyjskiego pisarza. Reżyser przekłada na dzieło sceniczne wszystkie siedem scen Oświadczyn bez żadnych skrótów oraz dodanych partii tekstu. Ósma scena w scenariuszu Pawłowicza to początek jednoaktówki Niedźziedź. Autor przedstawienia 33 omdlenia, dalej co do słowa przekłada na język teatru żart sceniczny Czechowa. Jedynym odstępstwem, na jakie sobie pozwala, jest inne nazwanie głównej bohaterki. Właścicielka ziemska, wdowa Helena Popowa, na deskach Teatru Bagatela to Łomowa. Choć jednoaktówki Czechowa pochodzą z różnych okresów, to w zestawieniu ze sobą tworzą spójny tekst dramatu w trzech atakach. Dzieje się tak ponieważ twórczość Czechowa, na tle innych rosyjskich dziewiętnastowiecznych pisarzy, wyróżnia się porzuceniem obszernych i szczegółowych opisów postaci, miejsca akacji i okoliczności fabuły. Czechow w krótkich formach skupia się zazwyczaj na jednym przymiocie głównego bohatera. Zaś same cechy charakteru ujawnia czytelnikowi nie w nużących opisach, ale w dialogach postaci. Zarówno Natalia Stiepanowna (Oświad$c z y n)$, Helena Popowa (Niedźziedź), jak i Mierczutkina (Jubileusz) to kobiety przekorne i porywcze, do których zawsze musi należeć ostatnie słowo.

Ogrody Nauk i Sztuk nR 2021 (11) 
„NATALIA

Ja... ja też jestem szczęśliwa.

CZUBUKOW

Kamień z serca... Uf

NATALIA

Ale mimo wszystko, niech pan przynajmniej teraz przyzna, że Zagraj jest gorszy od Zabija.

ŁOMOW

Lepszy!

NATALIA

Gorszy!

CZUBUKOW

No, zaczyna się szczęście rodzinne! Szampana!

ŁOMOW

Lepszy!

NATALIA

Gorszy! Gorszy! Gorszy!

CZUBUKOW

Szampana! Szampana!" (Pawłowicz 1989).²

W twórczości Czechowa Helena Popowa posiada ten sam wachlarz cech, co Natalia Stiepanowna. Wdowę od bohaterki Oświadczyn odróżnia przesadna patetyczność. $\mathrm{W}$ przedstawieniu Pawłowicza, tak jak u rosyjskiego pisarza, atrybut ten jest następstwem śmierci męża. Objawia się on przesadnym demonstrowaniem żałoby przed służbą. Mimo że minęło już sporo czasu od śmierci męża, kobieta nigdzie nie wychodzi oraz nie przyjmuje gości. Służbie stale powtarza, że pragnie zachować wierność zmarłemu mężowi, choć tak naprawdę jest młoda, atrakcyjną kobietą. Zarówno bohaterka 33 omdleń, jak i Niedźziedzia z domu chcą uczynić swój grobowiec. W swoim umartwianiu się lubią słuchać pochlebstw lokaja Łuki. Inne rysy charakteru Łomowej pozostają w zasadzie bez zmian. Dalej jest to kobieta przekorna i porywcza. Cechy te dają o sobie szczególnie znać, kiedy Smirnow brutalnie wkracza do jej domu, aby odzyskać pieniądze, które pożyczył nieboszczykowi i przez to nie pozwala bohaterce „cierpieć w spokoju".

\section{„ŁOMOWA}

Powiedziałam, że jest Pan niedźwiedź i monstrum.

SMIRNOW

Przepraszam, jakim prawem Pani mnie znieważa? [...] A pani myśli, że jeżeli pani jest poetyczną istota, to ma pani prawo znieważyć bezkarnie? Tak? To na pojedynek! [...] Na pistolety.

ŁOMOWA

Niedźwiedź! Niedźwiedź! Niedźwiedź! [...] Chcę się Pan strzelać? Proszę! [...] W tej

2 T. Pawłowicz, 33 omdlenia, scenariusz b.m.w.b.r.w., wystawiony 8.04.1989r. w Teatrze Bagatela im. Tadeusza Boya-Żeleńskiego w Krakowie. Scenariusz został udostępniony autorce pracy przez p.o. Dyrektora Renatę Derejczyk. 
chwili. Po mężu zostały pistolety... Zaraz je tutaj przyniosę. Z jaką rozkoszą wpakuje kulę w to miedziane oczko. Niech Pana licho weźmie. /wychodzi/

\section{SMIRNOW}

Zastrzelę jak kurczaka. [...] To ci kobieta! To rozumiem! Prawdziwa kobieta, nie ciepłe kluski, nie mazgaj, ale ogień, proch, rakieta! Aż zabijać szkoda!" (Pawłowicz 1989).

Smirnow, podobnie jak Łomowa, jest porywczej natury. Objawia się to $\mathrm{w}$ bezmyślnym sprzeczaniu się i chęci procesowania o wszystko. Natomiast Smirnowa w postępowaniu. Jego usposobienie sprawia, że nie widzi nic złego w pojedynkowaniu się z kobietą. Ponadto, tak samo jak Łomowa ma tendencje do hipochondrii. Łomowa, w odróżnieniu od Smirnowa, była bardziej spolegliwa w stosunku do kobiet. Łomowa nie bez przyczyny nazywa Smirnowa niedźwiedziem. Warto wspomnieć, że w rosyjskich bajkach i legendach niedźwiedź był symbolem głupiego barbarzyńcy, którym straszono niegrzeczne panny.

We wszystkich trzech jednoaktówkach Czechowa, kobiety i mężczyźni mają podobne cechy charakteru, co reżyser wykorzystał w bardzo sprytny sposób, łącząc wszystkie utwory w jedno przedstawienie. Każda z części inscenizacji przedstawia inny etap w życiu kobiety i mężczyzny. Na samym początku spektaklu Natalia to porywcza i uparta panna na wydaniu. W drugiej części adaptacji reżyser uposaża ją w kolejny atrybut zaczerpnięty z Niedźwiedzia, Czechowa, czyniąc z niej porywcza, ale przesadnie patetyczną wdowę, która ponownie wychodzi za mąż. Natomiast w ostatniej, trzeciej części twórca przedstawienia odkrywa przed widzem jeszcze inną właściwość kobiety (tym razem zaczerpniętą z Jubileuszu Mierczutkina) - jest to uparta manipulantka, która sprawia wrażenie niegroźnej, gadatliwej żony.

W trzeciej części przedstawienia, czyli scenicznej adaptacji utworu Jubileusz możemy zauważyć, że porywczość w stosunku do kobiet to cecha, która charakteryzuje nie tylko Smirnowa (Niedźwiedź), ale Chirina (Jubileusz). Problem porywczej natury u bohaterów Czechowa autor inscenizacji przedstawia w humorystyczny sposób. Należy pamiętać, że pisarz był synem, wykupionego z poddaństwa, chłopa pańszczyźnianego, który żył w przeświadczeniu, że bez kar cielesnych nie można wychować skutecznie dzieci. Stąd pisarz często obdarzał swoich bohaterów porywczą naturą.

„Pewnego razu spytał sąsiada z ławy szkolnej:

- Jak często łoją ci w domu skórę?

- Mnie? - zdziwił się kolega. - Nigdy.

Antoni się zdumiał. Odkrył, że poza światkiem, w którym żył, istnieje inny, może nieco lepszy" (Modzelewska 1975, 162).

W Jubileuszu Czechowa Chirin to buchalter Szypuczina. Buchalter traktuje kobiety jak zło konieczne. Chirina można określić jako alter ego Smirnowa (Niedźwiedź). Sam Szypuczin jest spolegliwy i nie umie odmawiać kobietom. Mimo że często wyprowadzają one Andriea Szypuczina z równowagi, to nie potrafi on zachowywać się wobec nich ordynarnie i pozostaje w każdej sytuacji kulturalny i szarmancki. Usposobienie Szypuczina wobec kobiet daje o sobie znać już na samym początku trzeciej części przedstawienia, które rozpoczyna się od następującego dialogu:

Ogrody Nauk i Sztuk nR 2021 (11) 


\section{„SZYPUCZIN \\ Co za bzdura! \\ CHIRIN}

Wiem, że pan dla szyku napuści ich dziś pełną salę, ale niech pan uważa one panu wszystko popsują. One są przyczyną wszelkiego zamętu i szkody.

\section{SZYPUCZIN}

Wprost przeciwnie, towarzystwo kobiet uszlachetnia!...

\section{CHIRIN}

Tak... Pańska małżonka to, zdaje się osoba wykształcona, a w ubiegłym tygodniu w poniedziałek palnęła coś takiego, żem potem przez dwa dni tylko ręce rozkładałem(...)" (Pawłowicz 1989).

Pawłowicz pomija cały początkowy dialog Szypuczina i Chirina, traktujący o uroczystych przygotowaniach do obchodów piętnastolecia istnienia banku. Reżyser dokonuje niniejszego skrótu prawdopodobnie dlatego, że same uroczystości mają marginalne znaczenie w kontekście całego przedstawienia. Jednoaktówki Czechowa, z których składa się adaptacja sceniczna w komiczny sposób przedstawiają relacje damsko - męskie. Ponadto, zarówno druga część przedstawienia, jak i jednoaktówka Niedźwiedź, kończą się w sceną w której Smirnow zastanawia się nad własnymi uczuciami.

\section{„SMIRNOW}

Jaki ja jestem zły na siebie! Zakochałem się jak uczniak, klęczałem... aż ciarki po skórze przechodzą... Kocham panią! Bardzo mi to było potrzebne(...)" (Pawłowicz 1989).

Należy pamiętać, że zarówno w utworze Czechowa, jak i w inscenizacji Pawłowicza, Smirnow jest porywczy wobec kobiet, chce się pojedynkować z główną bohaterką. Przechwala się, że dwanaście kobiet porzucił w swoim życiu, a dziewięć jego porzuciło. Wspomina także, że trzy razy pojedynkował się o kobietę. Dodaje, iż pół majątku stracił z powodu płci pięknej, dlatego więcej w imię miłości nie będzie robić z siebie błazna. Reżyser, zestawiając ze sobą tak dwie różne postawy, jakie prezentują Smirnow oraz Szypuczin, podkreśla komizm utworów Czechowa. Warto dodać, że na scenie Smirnowa i Szypuczina gra ten sam aktor, co jeszcze bardziej wyolbrzymia czechowowską karykaturalność. Przy tym trzeba nadmienić, że sam pisarz z zasady był przeciwnikiem małżeństw, ponieważ nie wierzył w szczęście matrymonialne (Modzelewska, 1975). Osoby z otoczenia Czechowa miały za sobą wiele nieudanych związków a jego jedyna siostra dwa razy odmówiła zamążpójścia.

W odróżnieniu do Oświadczyn i Niedźwiedzia, Pawłowicz nie adaptuje całego tekstu Jubileuszu. W 33 omdleniach zawiera tylko wątki związane z Andrejem Szypuczinem, Kuźmą Chirynem oraz Nastazją Mierczutkiną. Perypetie Nastazji odgrywa Łomowa. $\mathrm{W}$ ten sposób reżyser nie wprowadza na scenę kolejnej postaci, tylko z historii Mierczutkiny tworzy kontynuację życiorysu Łomowej. Adaptator w przedstawieniu nie uwzględnia także zakończenia Jubileuszu i wizyty urzędników, do której skrupulatnie przygotowywał się prezes towarzystwa kredytowego. Jest to wynikiem skreśleń jakich dokonał reżyser. Wizytacje Szypuczinowi zniszczyła jego żona Tatiana 
oraz Mierczutkina. W utworze Czechowa Tatiana jest głupiutką trzpiotka, której charakterystyka nie pasuje do żadnej z bohaterek. Ponadto, jak zostało to wspomniane wcześniej, wątek wizytacji nie pasuje do całej tematyki przedstawienia.

\section{Podsumowanie}

Reasumując, 33 omdlenia, wystawione w Teatrze Bagatela, to pierwsza adaptacja teatralna rosyjskich klasyków po 1989 roku w Krakowie. Tadeusz Pawłowicz przełożył na język teatru trzy jednoaktówki Czechowa: Oświadczyny, Niedźwiedź i Jubileusz. Wymienione utwory są bardzo krótkie i stanowią idealny przykład licznych zwięzłych utworów Czechowa, określanych mianem żartów scenicznych. Stąd fabuła i długość samego przedstawienia oraz scenariusza Pawłowicza nie jest zbyt obszerna. Ponadto, reżyser przekładając dzieło literackie na dzieło sceniczne nie dopisał żadnych dodatkowych partii tekstu oraz nie dodał autorskich wątków. Tym samym twórca teatralny w przystępny sposób zaprezentował krakowskiej publiczności najważniejsze idee twórczości Antoniego Czechowa, zawarte w Oświadczynach, Niedźwiedziu i Jubileuszu. Adaptacja Pawłowicza to esencjonalne dialogi, które w humorystyczny sposób ukazują przywary głównych bohaterów, bez zbędnych wątków dodatkowych, monologów i nużących opisów; podobnie jak większość czechowowskich utworów. Dodatkowo warto zauważyć, że inscenizacja Pawłowicza nie obfituje w wątki zaczerpnięte z życiorysu pisarza oraz z kultury rosyjskiej XIX wieku. Być może dzieje się tak, ponieważ Czechow był bardzo skrytym artystą i sam deklarował, że nie lubi opowiadać o swoim życiu. Jednak warto podkreślić, że niewielu odbiorców przedstawienia mogło wysnuć takie wnioski, ponieważ zostało ono potraktowane marginalnie przez ówczesną publicystykę, w której dominowała tematyka związana $\mathrm{z}$ transformacjami ustrojowymi.

\section{Bibliografia}

[1] Brak autora, (1989). Warto wiedzieć i skorzystać. „Dziennik Polski” (Rok XLV, nr 81), s. 8

[2] Hübner, Z. (2014). Sztuka reżyserii, Warszawa: Fundacja Teatru Myśli Obywatelskiej im. Zbigniewa Hubnera.

[3] Modzelewska, N. (1975). Pisarz i miłość: Dostojewski, Czechow, Warszawa: Ludowa Spółdzielnia Wydawnicza.

[4] Pawłowicz, T. (1989). 33 omdlenia. Scenariusz teatralny, niepublikowany, powielany wydruk komputerowy.

[5] Sinko, G. (1982). Opis przedstawienia teatralnego - problem semiotyczny, Wrocław: Zakład Narodowy im. Ossolińskich.

[6] Strzelecki, R. Guźlak, G. (2010). Czechow wspótcześnie, Bydgoszcz: Wydawnictwo Uniwersytetu Kazimierza Wielkiego.

[7] Śliwowski, R. (1989). Antoni Czechow, Warszawa: Wydawnictwo Uniwersytetu Warszawskiego. 